\title{
PEMBERDAYAAN LEMBAGA PENDIDIKAN FORMAL DI BANGKA DALAM PENANAMAN GEREJA BARU
}

Daniel Abdi, Yanto Paulus Hermanto

Sekolah Tinggi Teologi Kharisma Bandung

danielabdi510@gmail.com,yantopaulush@gmail.com

\begin{abstract}
Social concern in the formation of Christian character and faith through non-profit educational institutions that have not been a special concern of Christians. Meanwhile, Christ must be the main part in the character of church leadership and secular leadership in the future. Through formal educational institutions such as Kindergartens and Elementary Schools, the church can contribute in participating in the intellectual life of the nation from an early age with the principle of 'fearing God'. Educational institutions are long-term in the formation of the character of Christ which plays an important role for each generation in the welfare and salvation of generations. The Sustainability Service can be expanded to carry out joint activities. the evidence of the new church is as true church growth. Several strategies developed through the empowerment of formal educational institutions, and under the leadership of the Holy Spirit, are expected to contribute to the planting of new churches.
\end{abstract}

Keywords: Social Care, Formal educational institutions, Fear of God

\begin{abstract}
Abstrak
Kepedulian sosial dalam pembentukan karakter dan iman Kristen melalui lembaga pendidikan non-profit belum menjadi perhatian khusus dari orang Kristen. Sementara karakter Kristus harus menjadi bagian utama dalam kepemimpinan gereja dan kepemimpinan sekuler kedepan. Melalui lembaga pendidikan formal Taman Kanak-kanak dan Sekolah Dasar, gereja dapat berkontribusi dalam turut serta mencerdaskan kehidupan bangsa sejak dini dengan prinsip 'takut akan Allah". Lembaga pendidikan adalah pelayanan jangka panjang dalam pembentukan karakter Kristus yang berperan penting bagi setiap generasi pada kesejahterahan serta keselamatan generasi. Kesinambungan pelayanan tersebut dapat memperluas gereja melakukan tugasnya. Penanaman gereja baru adalah sebagai bukti pertumbuhan gereja yang sesungguhnya. Beberapa strategi dibangun melalui pemberdayaan lembaga pendidikan formal, dan dibawah pimpinan Roh Kudus diharapkan dapat memberikan kontribusi dalam penanaman gereja baru.
\end{abstract}

Kata kunci : Kepedulian Sosial, Lembaga pendidikan formal, Takut akan Tuhan

\section{PENDAHULUAN}

Masalah sosial yang sering terjadi khususnya di daerah begitu kompleks. Hal ini ditunjukan melalui persentase variasi tingkat kemiskinan yang masih 
terlihat dibebearapa provinsi. ${ }^{1}$ Rendahnya tingkat pendidikan menjadi salah satu potensi kemiskinan yang terjadi. ${ }^{2}$ Kelangkaan kepekaan sosial terhadap lingkungan menjadi penghambat di dalam penanaman gereja. Oleh sebab itu bagaimana gereja masuk dalam pelayanan praktis di masyarakat ini melalu kondisi sosial yang ada dengan harapan penanaman gereja baru dapat berjalan dengan smooth. Kurangnya pelayanan pendidikan yang memadai di daerah-daerah tertentu seringkali menjadi masalah dalam lembaga pendidikan formal. Hal ini disebabkan karena kurangnya tenaga pengajar yang berminat untuk masuk ke daerah-daerah terpencil dan karena akses yang cukup jauh dari kota kecamatan. Jika gereja tidak tidak masuk dalam pelayanan pendidikan formal ini sejak dini maka lembaga non-kristenpun akan merespon pelayanan tersebut. Dengan kondisi seperti ini hampir bisa dipastikan pelayanan gereja melalui pelayanan pendidikan akan sulit masuk berkembang di suatu daerah dan kecil kesempatan penanaman gereja melalui akses lembaga pendidikan.

Lembaga pendidikan formal adalah jalur pendidikan yang terstruktur, sistematis dan berjenjang dengan syarat-syarat yang jelas untuk memberikan pelayanan pendidikan. Yang menjadi dasar utamanya adalah kualitas pendidikan yang selalu berubah mengikuti perkembangan wawasan dan membentuk suatu karakter penerus bangsa. Dengan kehadirannya akan diikuti perubahan pola pikir masyarakat bahwa pendidikan dibutuhkan bagi seluruh anak bangsa untuk satu perubahan yang lebih baik lagi. ${ }^{3}$ Oleh sebab itu bagaimana gereja harus hadir dalam penyedia pelayanan pendidikan tersebut dengan ciri khas yang berbeda yaitu iman yang benar di dalam nama Tuhan Yesus Kristus. Kemajuan satu bangsa kedepan ditentukan oleh karakter generasi yang ada sekarang yang menjadi landasan utama. ${ }^{4}$

Penulis akan meneliti peran "Sekolah Sehati" sebagai lembaga pendidikan yang telah berhasil menanam satu gereja lokal. Kiat-kiat apa saja yang mereka miliki sehingga berhasil mendirikan gereja baru di lingkungan sekitarnya. Maksud penelitian ini adalah untuk memberikan wawasan yang luas bagi lembagalembaga pendidikan untuk mengembangkan kompetensinya terutama dalam menanam gereja baru.

\footnotetext{
${ }^{1}$ Achmad Bahauddin, Agustina Fatmawati, and Febrianti Permata Sari, "Analisis Clustering Provinsi Di Indonesia Berdasarkan Tingkat Kemiskinan MENGGUNAKAN ALGORITMA KMEANS,” Jurnal Manajemen Informatika dan Sistem Informasi 4, no. 1 (2021).

2 "Analisis Pengaruh PDRB, Pengangguran Dan Pendidikan Terhadap Tingkat Kemiskinan Di Pulau Jawa Tahun 2009-2016," Economics Development Analysis Journal 7, no. 1 (2018).

${ }^{3}$ Bambang Hermanto, "Perekayasaan Sistem Pendidikan Nasional Untuk Mencerdaskan Kehidupan Bangsa," FOUNDASIA 11, no. 2 (2020).

${ }^{4}$ Kalis Stevanus and Nathanail Sitepu, "Strategi Pendidikan Kristen Dalam Pembentukan Warga Gereja Yang Unggul Dan Berkarakter Berdasarkan Perspektif Kristiani," SANCTUM DOMINE: JURNAL TEOLOGI 10, no. 1 (2020).
} 


\section{METODE PENELITIAN}

Dalam peneleitian ini digunakan pendekatan kualitatif dengan mengumpulkan data-data dari buku atau jurnal teologi dan jurnal umum yang berkaitan dengan pendidikan dan penanaman gereja baru. Selanjutnya penggalian data tersebut dilakukan untuk menemukan langkah-langkah praktis yang diambil dalam penanaman gereja baru melalui pemberdayaan lembaga pendidikan formal yang ada.

Dengan mengawali penelitian melalui lembaga pendidikan formal Sekolah Sehati dalam pembentukan karakter siswa yang dibawa pada pengenalan Allah yang benar, maka sejauh mana pengaruh sikap "takut akan Tuhan" dalam implementasinya membawa perubahan yang signifikan. Demikian juga sejauh mana kepedulian sosial melalui pendidikan ini akan membuka kesempatan gereja yang lebih luas lagi dalam melakukan pelayanan yang ada, sehingga kehadiran gereja menjadi suatu kebutuhan rohani yang dirasa perlu. Kemudian tinjauan Alkitab dari Perjanjian Lama (PL) dan Perjanjian Baru (PB) menjadi dasar penggalian untuk bagaimana penanaman gereja baru tersebut dapat berjalan dengan smooth.

\section{HASIL DAN PEMBAHASAN}

Hasil dan pembahasan karya ilmiah ini diuraikan sebagai berikut:

\section{Kepedulian Gereja Terhadap Masalah Sosial}

Angka kemiskinan di Bangka cukup tinggi, hal ini dikarenakan banyaknya angkatan kerja mulai dari usia 15 tahun sudah menggeluti pekerjaan sektor imformal seperti pertambangan timah, perkebunan (sawit, lada, singkong racun), nelayan dengan pendapatan yang rendah. ${ }^{5}$ Ada juga dari mulai angkatan tersebut yang merantau tanpa ijazah atau tanpa keahlian yang mumpuni dalam bersaing di kota-kota besar, sekalipun ada yang berhasil namun banyak juga yang tidak berhasil. Dalam permasalahan sosial ini terlihat kepedulian pendidikan baik formal maupun imformal yang perlu adanya pembenahan didaerah-daerah tertentu, khususnya daerah-daerah yang kurang mendapat akses pendidikan yang memadai.

Dalam mengatasi masalah sosial pada dunia pendidikan baik formal maupun imformal, sudah seharusnya gerejapun berperan didalamnya. Matius pasal 5 berbicara tentang khotbah Yesus dibukit untuk mengajarkan setiap orang percaya akan kepedulian sosial untuk mempermuliakan Bapa yang di sorga. Dan pelaku firman Tuhan layak menduduki tempat yang tinggi di dalam Kerajaan Sorga. Kehidupan kekristen bukan saja berbicara untuk mendapatkan keselamatan yang kekal, namun Tuhan Yesus sendiri mengajarkan untuk menjadi "garam dan terang dunia". Demikian juga didalam Injil sinoptik lainnya kepedulian Yesus terhadap situasi dan kondisi yang ada menjadi penekanan secara naratif. Oleh sebab itu setiap orang percaya dituntut untuk mengusahakan kesejahterahan kota (Yer 29:7) yang berarti setiap orang percaya mempunyai kepedulian sosial

${ }^{5}$ Gebila Gebila and Ayu Wulandari, "PENGARUH PENGANGGURAN TERHADAP KEMISKINAN DI KABUPATEN BANGKA TAHUN 2009-2018,” Jurnal Manajemen Kompeten 3, no. 2 (2021). 
terhadap kota bahkan negara. Kata "mengusahakan" yang dimaksud adalah mencakup; mengerjakan, mengikhtiarkan dan menciptakan suatu karya nyata dalam kontribusinya.

Dalam pelayanan misi kekristenan bukan saja menyentuh hal-hal yang sifatnya kerohanian yang dilayani tetapi menyentuh kebutuhan-kebutuhan sosial juga. ${ }^{6}$ Berangkat dari pelayanan Yesus inilah kepedulian gereja terhadap pendidikan hadir di pulau Bangka melalui Sekolah Sehati.

\section{Kepedulian Gereja Melalui Pemberdayaan Lembaga Pendidikan Formal}

Peran kepedulian gereja terhadap lembaga pendidikan formal sangat mempengaruhi kesinambungan kesejahterahan sosial di masa yang akan datang. Melalui pendidikan formal dengan dasar iman Krsiten di Sekolah Sehati - Bangka, menerapkan motto yang diambil dari Amsal 1 ayat 7: 'Takut akan TUHAN adalah permulaan pengetahuan”. Motto sekolah tersebut diterapkan kepada peserta didik sejak usia dini yaitu mulai dari Pendidikan Anak Usia Dini (PAUD) hingga dan tingkat Sekolah Dasar. Dalam rentang usia ini peluang penginjilan akan semakin luas dan berkesinambungan. Sehingga melalui sekolah Sehati ditekankan tentang keberadaan segala pengetahuan karena adanya Sang Pencipta dalam awal penciptaan yaitu TUHAN yang menjadi penekanan utama. Melalui motto sekolah Sehati, Injil sudah diberitakan.

Pelayanan pendidikan adalah pelayanan jangka panjang yang harus mempunyai ketahanan eksistensi yang tinggi supaya setiap yang telah diawali tidak menjadi sia-sia. Oleh sebab itu seluruh komponen dari anak-anak Tuhan yang terpanggil mulai dari donatur, tenaga pendidik dan karyawan harus bersinergi dengan tanggung jawab dan komitmen akan kesetiaannya dalam institusi tersebut kepada TUHAN. Perhatian pemerintah dan kerja sama melalui dinas terkait juga menjadi satu variabel dalam ketahanan lembaga pendidikan formal. Kepedulian sosial dalam sekolah Sehati ini berorientasi menjadi sekolah yang non-profit, dengan memberi perhatian juga kepada setiap keluarga peserta didik dengan kemampuan ekonomi tertentu yang perlu mendapatkan perhatian. Perhatian kepada anak-anak bangsa yang membawa bangsa ini kepada TUHAN menjadi fokus utama yaitu untuk menjadi "terang dan garam dunia". Gereja tidak boleh lengah dan tertinggal dalam pelayanan pendidikan formal sejak dini dalam kontribusi misi iman Krsiten.

Adapun tingkat kepercayaan masyarakat untuk menyekolahkan anakanaknya menjadi variabel penting lainnya di dalam sekolah, oleh sebab itu setiap guru dan karyawan harus memproyeksikan kepedulian gereja terhadap sekolah dan masyarakat dengan menghasilkan output yang terbaik yaitu peserta didik yang berkarakter, berprestasi dan dapat bersaing di sekolah tingkat lanjutan. Membangun serta menyadarkan semua komponen orang percaya terhadap

\footnotetext{
${ }^{6}$ Herry Susanto, “Gereja Sebagai Umat Allah Dan Rekan Negara,” Jurnal Jaffray 17, no. 1 (2019).
} 
kepedulian atas kesejahterahan kota dan bangsanya melalui sekolah akan berdampak bagi lingkungan. $^{7}$

Respon yang baik didalam lingkungan akan menjadi modal dalam pelayanan-pelayanan gereja yang lebih luas lagi. Dimulai dari ibadah bersama dalam kepedulian kerohanian siswa yang diadakan secara rutin menjadi gerakan khusus dalam pendidikan karakter kekristenan yang bersinergi dengan semua guru yang ada. ${ }^{8}$ Karakter kekristenan adalah output yang pasti terlihat dan menjadi surat pujian yang terbuka dan terus berkembang secara progresif di dalam setiap orang percaya. $^{9}$

Pentingnya kepedulian gereja terhadap lembaga pendidikan dasar formal yang berkarakter dan berkualitas adalah : satu, pendidikan dibutuhkan bagi pemimpin gereja dan dunia sekuler. Dua, pendidikan Kristen sejak dini akan menjadi berkat di masa yang akan datang. Dengan demikian Amanat Agung Tuhan Yesus hadir didalam lembaga pendidikan formal.

\section{Penanaman Gereja Baru}

Gereja yang bertumbuh adalah gereja yang menanamkan gereja baru. Meluasnya tugas gereja dalam pelayanan kepedulian sosial melalui lembaga pendidikan akan dirasakan sangat dibutuhkannya kehadiran gereja. Oleh sebab itu penanaman gereja baru adalah sebagai respon atas pelayanan yang sudah terbentuk. Melalui data-data siswa yang ada disekolah, dapat diketahui latar belakang siswa yang valid untuk melakukan pendekatan-pendekatan di masyarakat. Dalam setiap kondisi sosial yang ada gereja mempunyai peluang untuk melakukan tugasnya, dengan demikian kehadiran gereja berdampak.

Pemberdayaan lembaga pendidikan formal dalam pengenalan budaya dan kearifan lokal dilakukan melalui pembelajaran ekstrakulikuler pada muatan lokal yang ada. Melalui kerjasama dengan masyarakat sekitar dalam hal yang berkaitan dengan mata pencaharian mereka maka secara tidak langsung telah mempromosikannya. Contohnya belajar membuat kerupuk kemplang atau panganan lainnya sebagai pendekatan kepada masyarakat. Letak geografispun dapat menjadi tema dalam belajar mengajar misalnya mengangkat tema-tema laut sebagai ciptaan Tuhan yang memberikan hasil, dan masih banyak celah melalui lembaga pendidikan dimana gereja dapat melakukan pendekatan. Sinergi terhadap pemerintah daerah terkait dari tingkat desa, kecamatan, kabupaten dan seterusnya dapat menjadi dampak istimewa tersendiri ketika satu lembaga pendidikan formal ini dapat berprestasi di tingkat yang lebih tinggi untuk mewakili daerahnya masing-masing, misalnya melalui Olimpiade Olahraga Siswa Nasional (O2SN)

\footnotetext{
${ }^{7}$ Rita Evimalinda, Rikardo Dayanto Butar-butar, and Efvi Noyita, "Membangun Semangat Kebangkitan Nasional Melalui Konten Pendidikan Agama Kristen Multikultural," KHARISMATA: Jurnal Teologi Pantekosta 4, no. 1 (2021).

${ }^{8}$ Arozatulo Telaumbanua, "Peranan Guru Pendidikan Agama Kristen Dalam Membentuk Karakter Siswa," FIDEI: Jurnal Teologi Sistematika dan Praktika 1, no. 2 (2018).

${ }^{9}$ Hardi Budiyana, "Kristus Sebagai Pusat Misi Pendidikan Kristen Untuk Mewujudkan Murid Kristus Dalam Gereja Lokal," TELEIOS: Jurnal Teologi dan Pendidikan Agama Kristen 1, no. 1 (2021).
} 
dan Festival dan Lomba Seni Siswa Nasional (FLS2N). Semua pemberdayaan tersebut hanya untuk mempermuliakan nama Tuhan dalam mengusahakan kesejahterahan kota (Yer 29:7).

Dalam implementasi dilapangan penanaman gereja baru bukanlah hal yang mudah, terlebih lagi dalam hal perijinan lingkungan yang mengacu pada Surat Keputusan Bersama dua menteri yang menjadi Peraturan Bersama Menteri Agama dan Menteri Dalam Negeri perihal pendirian rumah ibadah seringkali membatasi ruang gerak misi penanaman gereja baru sekalipun gereja telah konsisten melakukan tugasnya untuk berdampak bagi masyarakat. ${ }^{10}$ Oleh sebab itu perlu peran Roh Kudus dalam memimpin penanaman gereja baru dan doa menjadi kekuatan bagi setiap orang percaya. ${ }^{11}$ Dalam hal perijinan ini data statistik kekristenan menjadi variabel penting, oleh sebab itu setiap anak-anak Tuhan yang percaya harus masuk dalam baptisan air untuk selanjutnya gereja dapat mengeluarkan surat tanda baptisan air tersebut. Kemudian hal ini dapat ditindak lanjuti sebagai dasar perubahan kolom agama pada KTP di Kantor Pencatatan Sipil. Sebagai warga gereja dan warga negara harus berhati-hati dalam menyikapi hal ini, namun St., Francis de Sales pernah berkata "Nothing is so strong as gentleness. Nothing so gentle as real strength". Hal ini menunjukan bahwa kelembutaan adalah kekuatan nyata. ${ }^{12}$

Berjalan dibawah pimpinan Roh serta mengikuti peraturan pemerintah adalah sikap kelembutan kita. Didalam Efesus 4:2 berbicara lemah lembut disini berarti kesiapan rohani dan mental menghadapi segala tekanan dapat dengan tegas menerima beban dengan pengendalian emosi yang baik. Lemah lembut disini bukanlah kelemahan, dalam terjemahan bahasa Inggris "meekness" bukanlah "weakness" dan dalam bahasa Yunani " $\pi \rho \alpha o \tau \eta \varsigma$ - praotês" yang diambil dari kata sifat $\pi \rho \alpha o \varsigma$ - PRAOS adalah kata yang sulit diterjemahkan namun mempunyai makna ringang, perlahan, lembut, penurut dengan segala kesiapan yang ada. Kata ini menurut Aristoteles menggambarkan sikap ditengah-tengah antara marah yang teramat sangat (tidak terkontrol) dan tidak marah meskipun apapun yang terjadi. Sikap tersebut digambarkan juga seperti hewan yang sangat terlatih dan siap ditunggangi atau menerima beban. Dalam Perjanjian Baru kata Yunani $\pi \rho \alpha o \tau \eta \varsigma$ - praotês disini memiliki tiga makna yaitu : Taat akan kehendak Allah; siap diajar (mau menerima pengajaran); lemah lembut. ${ }^{13}$

Dalam hal penanaman gereja baru disini segala kesiapannya sesuai dengan SKB dua menteri menjadi strategi yang dengan lembut dipersiapkan. Mulai dari strategi atas dukungan lingkungan masyarakat dari yang terdekat, jumlah jemaat

\footnotetext{
${ }^{10}$ Gomar Gultom, "Seputari Ijin Rumah Ibadah Dari SKB Ke PBM,” ed. Gomar Gultom, 3rd ed. (Bidang Diakonia PGI, 2006), 114.

${ }^{11}$ Simon Simon and Semuel Ruddy Angkouw, "Perintisan Gereja Sebagai Bagian Dari Implementasi Amanat Agung," Manna Rafflesia 7, no. 2 (2021).

${ }^{12}$ Ibid.

${ }^{13}$ Rita Wahyu, "Sarapanpagi.Org,” 2021, https://www.sarapanpagi.org/buah-rohvt586.html\#p1359.
} 
gereja lokal dan rekomendasi pemerintah dari tingkat desa sampai kabupaten serta Forum Komunikasi Umat Beragama terkait menjadi modal penting selain yang terutama adalah doa mohon pimpinan Roh Kudus.

Penanaman Gereja baru akan membuka pintu yang lebih lebar lagi dalam membawa Amanat Agung Allah untuk keselamatan dan kesejahterahan kota. Ketika Tuhan hendak menghancurkan kota Sodom dan Gomora (Kej 18:16-33). Abraham sempat berbicara kepada Tuhan dan terjadilah tawar menawar kepada Tuhan sampai di angka sepuluh jumlah orang benar dimata Tuhan. Apa bila ada sepuluh orang benar saja di mata Tuhan maka Tuhan tidak akan menghancurkan kota tersebut. Namun yang terjadi adalah hanya Lot, isteri dan kedua ananya bahkan yang selamat dari murka Allah hanyalah Lot dan kedua anaknya. Istri Lot tidak selamat karena pada saat mereka lari dari hujan belerang dan api saat penghancuran kota tersebut kota tersebut, isteri lot lupa akan perintah Tuhan untuk tidak menoleh kebalakang maka dia menjadi tiang garam. Dalam hal ini jumlah orang benar menjadi penentu keselamatan kota. Hal inilah yang menjadi alasan misi dalam penanaman gereja baru supaya banyak orang dibenarkan dan menerima keselamatan serta damai sejahterah Allah.

\section{Strategi Lembaga Pendidikan Sehati Dalam Penanaman Gereja Baru}

Sebagi implementasi strategi lembaga pendidikan Sehati dalam penanaman gereja baru adalah menerapkan motto "Takut akan TUHAN adalah permulaan pengetahuan". Melalui motto sekolah Sehati diharapkan setiap siswa dapat mengenal siapa Tuhan Sang Pencipta dengan segala keberadaanNya dan apa yang menjadi karya terbesarNya bagi dunia. Melalui konsep pengenalan yang bersifat dinamis dan berorientasi pada masa yang akan datang dalam pemahaman kebudayaan yang dapat merefleksikan Injil akan memberikan alasan mengapa manusia harus "Takut akan Tuhan" yang menjadi sikap orang beriman. Namun demikian perlu diperhatikan agar jangan sampai masuk dalam kepercayaan sinkritisme. ${ }^{14}$

Parenting yang diadakan secara berkala selalu mengetengahkan tema besar tentang pertolongan TUHAN. Baik dalam keberadaan lembaga pendidikan Sehati serta dalam proses belajar dang mengajar dalam membentuk generasi emas dimasa yang akan datang. Oleh sebab itu bukan saja peran sekolah yaitu dalam hal ini adalah guru sebagai pendidik serta orang tua dirumah yang mendukung dalam proses belajar dan mengajar, namun ada peran Ilahi yang memampukan setiap peserta didik ini menyerap ilmu dan pembentukan karakter.

Eksistensi TUHAN dalam terjemahan bahasa Indonesia pada Perjanjian Lama merujuk kepada Allahnya orang Israel yang dikenal dengan $Y H W H$. Orang Isreael tidak berani menyebutkan nama yang kudus ini sehingga memberikan gelar (sebutan) yang sesuai untuk Allah adalah Adonay dan diterjemahkan dengan

\footnotetext{
${ }^{14}$ Yakob Tomatala, Pengantar Teologi Kontekstualisasi, 6th ed. (Malang: Gandum Mas,
} 2018). 
"Tuhan" dalam bahasa Indonesia. Sedangfkan Elohim sendiri menyatakan eksistensi Ilahi yang menyatakan bahwa "DIA" bukanlah malaikat, manusia ataupun keberadaan mahluk-mahluk yang lain. Tetragrammaton atau $Y H W H$ juga sering kali dalam pengucapannya disebut dengan Yehuwa, Yehova, Yehovah, Jehova, atau Jehovah, tergantung fonetik linguistik si pembaca yang dipengaruhi oleh keberadaan bahasa yang tersebar di deluruh dunia serta ketersediaan huruf dalam aksara yang dikenalnya. Dan Yahweh menjadi ejaan alternatif dari istilahistilah tersebut. Eksistensi TUHAN yang Mahakuasa, Mahakudus, Mahahadir dan Mahatahu inilah yang membentuk kesadaran manusia untuk mempunyai sikap "Takut akan TUHAN". Dengan sikap hormat dan tunduk pada keabsolutan TUHAN, mencari TUHAN dan memuliakanNya adalah fokus utama didalam kehidupan manusia. ${ }^{15}$

Dalam Perjanjian Baru penggenapan janji-janji TUHAN pada Perjanjian Lama digenapi, dimulai dari Injil yang mula-mula/protoevangelium (Kej 3:15) saat Adam jatuh dalam dosa. Bahwa akan ada seorang keturunan manusia yaitu yang merujuk pada pribadi Yesus akan menghancurkan pekerjaan Iblis untuk menyelamatkan manusia. Perjanjian Lama sangat detail mendeskripsikan nubuat atau janji-janjiNya mulai dari kelahiranNya, Dia yang disebut Imanuel (Yes 7:14; Mat 1:18-23: Luk 1:26-35), kematian seorang Mesias untuk memikul dosa manusia dan membenarkannya (Yes 53:11; Rm 5:18-19; 1 Yoh 2:1-2), bahkan seluruh kehidupan dan penderitaan-Nyapun di genapi sesuai dengan nubuat Perjanjian Lama. ${ }^{16}$

Pengenalan akan TUHAN Sang Pencipta begitu penting dalam setiap latar belakang kehidupan. Bukan saja menjadi sumber pengetahuan melainkan sumber kehidupan serta jaminan kehidupan yang pasti. Melalui pengenalan akan Tuhan yang benar, kesadaran sikap "Takut akan Tuhan" terbentuk. Implementasi hal ini sebagai strategi dalam Sekolah Sehati dilakukan melalui ibadah bersama seluruh kelas baik TK maupun SD, memberikan kesempatan siswa untuk terlibat dalam pelayanan ibadah bersama tersebut, memberikan ruang kesaksian dan pelayanan doa, Penekanan sikap jujur yang membuahkan hasil di masa yang akan datang menjadi fokus utama dalam setiap pembelajaran maupun dalam kehidupan seharihari. Hal inilah yang membedakan karakter siswa Sehati dalam pola kehidupannya. Dengan demikian akan terbentuk suatu komiunitas anak-anak Tuhan atau umat percaya di masa yang akan datang. Pelayanan misi gereja tidak hanya berhenti selepas mereka lulus dari sekolah Sehati, oleh sebab itu akan sengat diperlukan kehadiran gereja dalam pemenuhan kebutuhan rohani tersebut. Strategi utama didalamnya adalah membentuk karakter dengan iman yang benar

${ }^{15}$ Ril Tampasigi and Peniel C.D. Maiaweng, "Tinjauan Teologis Tentang Takut Akan Tuhan Berdasarkan Kitab Amsal Dan Implementasinya Dalam Hidup Kekristenan,” Jurnal Jaffray 10, no. 1 (2012).

${ }^{16}$ Rita Wahyu, Injil Salib Besorat Hatselav Protoevangelium \& Penggenapan Janji Eksegesis Peshat Naskah Ibrani, 1st ed. (Jakarta: Ekumene Literatur, 2020). 
di dalam Tuhan Yesus Kristus berkesinambungan dalam pemuridan yang tidak terbatas.

\section{KESIMPULAN}

Berdasarkan apa yang telah dibahas diatas, maka disimpilkan bahwa penanaman gereja baru yang membawa orang percaya adalah hal penting dalam keselamatan dan kesejahterahan kota. Gereja yang bertumbuh adalah gereja yang menanam gereja baru untuk kemuliaan Allah. Berangkat dari kepedulian gereja terhadap kondisi sosial yang ada maka melalui lembaga pendidikan formal dapat menanamkan nilai-nilai iman kekristenan dengan konsistensi yang berkeinambungan.

Diperlukannya strategi-strategi sesuai dengan konteks yang ada dalam penanaman gereja baru mulai dari pendekatan, persiapan dan eksekusi lapangan sehingga penanaman gereja baru dapat berjalan lebih smooth melalui pemberdayaan lembaga pendidikan.

\section{DAFTAR PUSTAKA}

Bahauddin, Achmad, Agustina Fatmawati, and Febrianti Permata Sari. "Analisis Clustering Provinsi Di Indonesia Berdasarkan Tingkat Kemiskinan Menggunakan Algoritma K-Means.” Jurnal Manajemen Informatika dan Sistem Informasi 4, no. 1 (2021).

Budiyana, Hardi. "Kristus Sebagai Pusat Misi Pendidikan Kristen Untuk Mewujudkan Murid Kristus Dalam Gereja Lokal." TELEIOS: Jurnal Teologi dan Pendidikan Agama Kristen 1, no. 1 (2021).

Evimalinda, Rita, Rikardo Dayanto Butar-butar, and Efvi Noyita. "Membangun Semangat Kebangkitan Nasional Melalui Konten Pendidikan Agama Kristen Multikultural.” KHARISMATA: Jurnal Teologi Pantekosta 4, no. 1 (2021).

Gebila, Gebila, and Ayu Wulandari. "PENGARUH PENGANGGURAN TERHADAP KEMISKINAN DI KABUPATEN BANGKA TAHUN 20092018." Jurnal Manajemen Kompeten 3, no. 2 (2021).

Gultom, Gomar. "Seputari Ijin Rumah Ibadah Dari SKB Ke PBM." edited by Gomar Gultom, 114. 3rd ed. Bidang Diakonia PGI, 2006.

Hermanto, Bambang. "Perekayasaan Sistem Pendidikan Nasional Untuk Mencerdaskan Kehidupan Bangsa.” FOUNDASIA 11, no. 2 (2020).

Rita Wahyu. Injil Salib Besorat Hatselav Protoevangelium \& Penggenapan Janji Eksegesis Peshat Naskah Ibrani. 1st ed. Jakarta: Ekumene Literatur, 2020.

Simon, Simon, and Semuel Ruddy Angkouw. "Perintisan Gereja Sebagai Bagian Dari Implementasi Amanat Agung." Manna Rafflesia 7, no. 2 (2021).

Stevanus, Kalis, and Nathanail Sitepu. "Strategi Pendidikan Kristen Dalam Pembentukan Warga Gereja Yang Unggul Dan Berkarakter Berdasarkan Perspektif Kristiani.” SANCTUM DOMINE: JURNAL TEOLOGI 10, no. 1 
(2020).

Susanto, Herry. "Gereja Sebagai Umat Allah Dan Rekan Negara.” Jurnal Jaffray 17, no. 1 (2019).

Tampasigi, Ril, and Peniel C.D. Maiaweng. "Tinjauan Teologis Tentang Takut Akan Tuhan Berdasarkan Kitab Amsal Dan Implementasinya Dalam Hidup Kekristenan.” Jurnal Jaffray 10, no. 1 (2012).

Telaumbanua, Arozatulo. "Peranan Guru Pendidikan Agama Kristen Dalam Membentuk Karakter Siswa." FIDEI: Jurnal Teologi Sistematika dan Praktika 1, no. 2 (2018).

Tomatala, Yakob. Pengantar Teologi Kontekstualisasi. 6th ed. Malang: Gandum Mas, 2018.

Wahyu, Rita. "Sarapanpagi.Org," 2021. https://www.sarapanpagi.org/buah-rohvt586.html\#p1359.

"Analisis Pengaruh PDRB, Pengangguran Dan Pendidikan Terhadap Tingkat Kemiskinan Di Pulau Jawa Tahun 2009-2016.” Economics Development Analysis Journal 7, no. 1 (2018). 